\title{
APPLIED METHODOLOGY FOR COMPUTATIONAL FORMULATION IN INTERNATIONAL EXPANSION STRATEGY OF TAIWANESE SEMICONDUCTOR INDUSTRY
}

\author{
Cher-Min Fong \\ Department of Business Management, National Sun Yat Sen University, Kaohsiung, Taiwan, R.O.C. \\ Hoang Linh Nguyen \\ Department of Business Management, National Sun Yat Sen University, Kaohsiung, Taiwan, R.O.C., \\ linhmc95@gmail.com
}

Follow this and additional works at: https://jmstt.ntou.edu.tw/journal

Part of the Engineering Commons

\section{Recommended Citation}

Fong, Cher-Min and Nguyen, Hoang Linh (2011) "APPLIED METHODOLOGY FOR COMPUTATIONAL FORMULATION IN INTERNATIONAL EXPANSION STRATEGY OF TAIWANESE SEMICONDUCTOR INDUSTRY," Journal of Marine Science and Technology: Vol. 19: Iss. 4, Article 11.

DOI: $10.51400 / 2709-6998.2183$

Available at: https://jmstt.ntou.edu.tw/journal/vol19/iss4/11

This Research Article is brought to you for free and open access by Journal of Marine Science and Technology. It has been accepted for inclusion in Journal of Marine Science and Technology by an authorized editor of Journal of Marine Science and Technology. 


\title{
APPLIED METHODOLOGY FOR COMPUTATIONAL FORMULATION IN INTERNATIONAL EXPANSION STRATEGY OF TAIWANESE SEMICONDUCTOR INDUSTRY
}

\author{
Cher-Min Fong* and Hoang Linh Nguyen*
}

Key words: international expansion strategy, knowledge development, foreign direct investment, semiconductor industry, cultural difference, MNEs.

\begin{abstract}
This study seeks to contribute to entry mode literature by introducing the concept of "corporate culture diversity". Compared to multinational enterprises (MNEs) from developed countries, Taiwan's MNEs have shorter history of internationalization. Therefore, international learning is critical to their entry modes. We examined an original determinant of entry mode choice, proposed and tested the operationalization for a new theoretical construct, namely "corporate culture diversity". Hypotheses were developed on the entry modes in relation to cultural diversity of a firm's international experience, a step beyond the conventional theory of how national cultural differences influence the international expansion strategy. The hypotheses were tested within the framework of organizational learning, using data on over 313 entries that 58 Taiwanese MNEs in semiconductor industry carried out in 25 countries and territories during 1986-2006.
\end{abstract}

\section{INTRODUCTION}

The model of knowledge development and increasing foreign market commitments has provided an important perspective on international business strategy of multinational enterprises (MNEs) [1,19]. According to this line of research, MNEs are considered to go through sequential and incremental process of internationalization when they enter in a foreign country and when they stretch out from one foreign country to another. In general, organizational learning is viewed as the driving force behind the internationalization process [1].

Paper submitted 12/24/09; revised 03/24/10; accepted 06/08/10. Author for correspondence: Hoang Linh Nguyen (e-mail: linhmc95@gmail.com).

*Department of Business Management, National Sun Yat Sen University, Kaohsiung, Taiwan, R.O.C.
This study is motivated by the following research observation and questions: why do different firms from the same home country have different modes of entry in the same host country with everything else being equal? Do learning factors affect the choices between different entry modes? Hence, it is imperative to understand firms' mode choices as being influenced by the dynamic context of learning by firms. In other words, we try to incorporate the stages of a firm's learning of the host country culture given the knowledge-based internationalization perspective. However, systematic research efforts linking enterprises' learning to their mode choice behaviors have been lacked in the literature. Among different types of learning involved in internationalization processes, this study focuses exclusively on firms' adaptation to host country cultures. Previous studies have analyzed how cultural barriers influence the frequency or probability of mode and ownership [1, 15]. Studies that are more recent implied that firms no longer enter foreign countries in small steps. Instead, "firms enter foreign environments either incrementally, as suggested by long-established theory, or by taking larger steps that may result in lower initial performance but, through learning and experience, lead to increased performance in future expansions" [2]. Additionally, some other meta-analyses considered entry modes research is relative new and covers different research perspectives, from transaction cost analysis, resource-based view, to institutional theory [5]. They identified many weakness and shortcomings of the entry mode studies. They also argued that past studies of international entry mode choice have tended to focus on several well-acknowledged theoretical frameworks while there appears to be a lack of consensus as to whether these are distinctive categories of entry modes that can be arrayed on a single dimension of increasing control, commitment, and risk. Similarly, Tihanyi et al. [30] found association between cultural distance and entry mode choice for US-based MNEs while Canabal \& White III [6] concluded that most of the entry mode studies during 1980-2006 have failed to explore into what happens once entry mode choice had made.

However, by examining only the effect of national culture distance on choice in their studies, the status of conceptu- 
alization seems limited. While the national culture distance may determine the amount of learning needed in general, other firm-level characteristics or unique capacity in learning need to be incorporated to develop a more comprehensive model to explain how a particular firm's learning contexts influence the entry mode choice. Consequently, the movement from a national level conceptualization to a corporate level conceptualization to construct an enhanced model to measure the effect of cultural factors on entry mode choice is worth doing.

\section{THEORETICAL FOUNDATION}

To address the above gaps in the literature, this study aims to develop an enhanced knowledge-based model consisting of two parts. First, a multinational enterprise's (MNE) mode choice is affected by the cultural learning contexts that are an MNE's need to learn and aptitude to learn a host country's culture. In this context, cultural distance and the MNE's prior experience in a host country culture determine the MNE's need to learn while corporate culture diversity corresponds to the MNE's aptitude to learn. The second part of the model sought to construct the operationalization of corporate culture diversity that corresponds to the MNE's aptitude to learn. An empirical test with a sample of foreign direct investments (FDIs) in the forms of wholly owned subsidiaries and joint ventures invested by Taiwanese MNEs in foreign countries during the period of 1986-2006 showed a strong support for the model.

Our interest is limited to the choice of entry mode in FDIs, defined as investment that involves ownership and confers effective management control [25]. Other forms of international expansion, including exporting, licensing, and non-equity alliances, do not constitute FDIs and are beyond the scope of this study. More specifically, consistent with these lines of research [3, 16, 20, 23, 24, 29], we examine two types of entry modes: wholly owned subsidiaries (wholly-owned subsidiary) and joint ventures (joint-venture).

Within the context of this study, three major variables are identified as critical in having effects on the decision of entry mode choice including: cultural distance, prior experience in host country culture, and corporate culture diversity.

\section{Cultural Distance between Home and Host Countries}

Cultural distance is defined as the degree of cultural difference between the host countries entered by an MNE and its home country [17]. Generally, managers tend to perceive higher uncertainties in foreign cultures [22]. Foreign expansion of firms, through exports and FDI, is very likely to involve uncertainty, since the environment in their home market is different from the one they will face in foreign markets [11]. In many cases, JVs will be used less often in high environmental uncertainty markets because adaptations cannot be made quickly due to the need for consent between parties [4]. We have empirically found the significance of cultural distance on entry mode choices in the researches of the international ex- pansions by US firms [15], foreign firms entered the US [9, 20] and foreign firms in China [23].

In the conceptualization of this study, cultural distance reflects the amount of learning necessary for the MNE to overcome cultural barriers and realize the anticipated benefit of the venture. Thus, it is expected that the higher the cultural distance is, the higher the need to learn will be. The assumption here is that the more dissimilar a new knowledge is from the existing body of knowledge, the more difficult to learn the knowledge will be. Organizational learning literature suggests, "Learning is cumulative and learning performance is greatest when the object of learning is related to what is already known" [10]. Thus, learning of new culture becomes more difficult as the culture is more dissimilar to the home country culture. Accordingly, joint-venture mode will be increasingly preferred to wholly-owned subsidiary mode, as cultural distance increases. Thus, we hypothesize:

Hypothesis 1. Cultural distance between the MNE's home country and a host country will have a negative effect on the selection of wholly-owned subsidiary mode over joint-venture mode.

\section{Prior Experience in Host Country Cultures}

Prior experience in host country was defined as the degree of the MNE's cumulated experience of the host country culture, prior to an entry. For a fixed amount of cultural distance (the target level of knowledge to be learned), as the MNE's prior experience in the host country culture (current level of knowledge) increases, the need to learn the culture should decrease. While this is a rather obvious notion of learning effect, the research effort to shed light on the cultural learning from this perspective has been limited. Probably the most distinguishable contribution has been that of the process-model of internationalization that explicitly views foreign expansion strategy as relatively small sequential steps of reducing uncertainties through organizational learning [27]. Some studies found prior experience with FDI leads to subsequent performance improvements [26]. Building on the above discussion, we expected that the higher the past learning is, the lower the cultural barrier and uncertainty will be, and thus the more likely wholly-owned subsidiary mode will be chosen over the joint-venture mode. Hence, we hypothesize:

Hypothesis 2. The MNE's prior experience in host country will have a positive effect on the selection of wholly-owned subsidiary mode over joint-venture mode.

\section{Corporate Culture Diversity}

While the above two factors are essentially concerned with the amount of learning needed to adapt to host country culture, in this study, we try to extend one step beyond and conceptualize that MNEs' aptitude to learn new culture should matter as well in explaining mode choices. In the context of this study, we first sought to define aptitude to learn as the firm-specific 
capacity to understand different characteristics of foreign cultures and accommodate them in operational settings. The assumption here is that some MNEs have higher learning capacity than others do. As the result, even with similar levels of cultural distance and prior experience in host country culture, two firms can still make different choices of modes if they possess different levels of aptitude to learn new cultures. A MNE with stronger learning capacity (exposed to more cultures), is more likely to select the wholly-owned subsidiary mode over the joint-venture mode.

Next, we identified a firm-level antecedent to the aptitude to learn as corporate culture diversity. This dimension is the degree of an MNE's exposure to different types of host country cultures. In the organizational learning literature, firm's absorptive capacity is defined as "ability to recognize the value of new external information, assimilate it, and apply it to commercial ends" [10]. Absorptive capacity supports further accumulation of technological knowledge, and technological advances support the further development of absorptive capacity in a cumulative, interactive and virtuous process during the catching-up stage. Absorptive capacity is therefore also concerned with the efficient use of knowledge acquired. Firms need the ability to use prior knowledge in the solution of practical problems that are commercially viable. Thus, absorptive capacity implies problem-solving skills that emerge directly as a result of attempts to assimilate external knowledge [12]. For the present study, absorptive capacity is viewed as a set of interrelated organizational capabilities used in acquiring and disseminating external knowledge [13]. Hence, the diversity of knowledge plays an important role in the absorptive capacity. To apply the concept of absorptive capacity, we view that the diversity of a firm's experience in foreign cultures increases its aptitude to adapt to any new culture in the future. Thus, we hypothesize:

Hypothesis 3. The MNE's corporate culture diversity will have a positive effect on the selection of wholly-owned subsidiary mode over joint-venture mode.

\section{METHODOLOGY}

\section{Data Compilation}

For testing the hypotheses, data of Overseas Investment of Taiwanese MNEs in semiconductor industry were obtained from Market Observation Post System (M.O.P.S), Taiwan Stock Exchange (TWSE). We then use the Taiwan Economic Journal database (TEJ) to gather for information on industry level and firm level variables. Because several information items of a firm were not subject to information disclosure required by TWSE in the 1980s and 1990s, a large number of cells in our data were missing. As the result, we decided to exclude the whole case if there was a missing cell in any single case. The final sample data consists of 313 subsidiaries established by 58 Taiwanese semiconductor-manufacturing firms that have operations in 25 countries and territories.

\section{Measurement of Variables}

\section{1) Dependent Variable}

The dependent variable in our study is the selection of wholly-owned subsidiary mode over joint-venture mode. Wholly-owned subsidiary was coded " 1 " while joint-venture was coded " 0 ".

\section{2) Independent Variables}

Three sets of independent variables were used: cultural distance, prior experience in host country, and corporate culture diversity. First, cultural distance was measured based on the operationalization of Hofstede's national culture scores [17]. In this study, a composite index was formulated based on the deviation along each of the four cultural dimensions of a country from Taiwan as follows:

$$
C D_{j}=\sum_{j=1}^{m} \sum_{i=1}^{4}\left\{\left(I_{i j}-I_{i T}\right)^{2} / \operatorname{Var}(i)\right\} / 4 \text {. }
$$

where

$I_{i j}$ : Index for cultural dimension $i$ th of foreign country $j$ th

$I_{i T}$ : Index for cultural dimension $i$ th of Taiwan

$\operatorname{Var}(i)$ : Variance of the index of the dimension $i$ th

Second, prior experience in host country was assigned as " 1 " if an MNE had at least one operation in the host country before the entry and " 0 " if it had no prior operation in the host country at the time of entry.

Third, corporate culture diversity would significantly explain the entry mode choice in addition to the traditional view of national culture determinant in expansion strategy of MNEs. This variable was defined at corporate level as the degree of a MNE's exposure to different foreign cultures. Since the operationalization of this variable was not available in the literature, a new measure of construction was proposed as follows. First, the more number of different country cultures a MNE had been exposed to, the higher its corporate culture diversity should be. Second, for a given number of country cultures to which a MNE was exposed, the more distant the foreign country cultures were from the MNE's culture, the higher its corporate culture diversity should be. Finally, for a given number of different country cultures with given cultural distances from the MNE's home country, MNEs were expected to have a higher degree of corporate culture diversity if the diversity among the set of foreign cultures was higher.

To incorporate the above aspects, a composite measure of cultural diversity was constructed based on two components: cultural distances and cultural set diversification. Cultural distances measured the degree of a MNE's exposure to foreign cultures by evaluating how distant a set of foreign cultures to which the MNE was already exposed is from the MNE's home country culture. In other words, it was the summation of terms of all cultural distances between MNEs' home country and 
host countries. On the other hand, the cultural set diversification measured how different a set of foreign cultures to which the MNE was exposed were diversified among themselves. In other words, it measured the culture diversity of each of the country cultures within a certain country cultural set where the MNE had its subsidiaries. Corporate culture diversity was then calculated as the summation of product terms of the two components along the four dimensions of country culture: Power distance, Individualism, Masculinity, and Uncertainty avoidance [18].

Using national culture score data for each country adopted from [18], we proposed the following formulation to calculate corporate culture diversity:

$$
C C D_{j k T}=\sum_{j=1}^{m} C D_{j T} * \sum_{j=1}^{m} \sum_{k=1}^{n} C D_{j k}
$$

where

$C C D_{j k T}$ : Corporate Culture Diversity

$C D_{j T}$ : The sum of cultural distance scores from Taiwan to the foreign countries where the Taiwanese MNE operates in the year of entry. The following formula was proposed for the calculation.

$$
C D_{j T}=\sum_{j=1}^{m}\left[\sum_{i=1}^{4}\left\{\left(I_{i j}-I_{i T}\right)^{2} / \operatorname{Var}(i)\right\} / 4\right]
$$

where

$I_{i j}$ : Index for cultural dimension $i$ th of foreign country $j$ th $I_{i T}$ : Index for cultural dimension $i$ th of Taiwan

$\operatorname{Var}(i)$ : Variance of the index of dimension $i$ th

$C D_{j k}$ : Cultural diversity among the set of foreign countries in which the Taiwan MNE operates in the year of entry. It serves as the coefficient of variation for $\mathrm{CD}_{j T}$. The following formula was proposed for the calculation:

$$
C D_{j k}=\sum_{j=1}^{m} \sum_{k=1}^{n}\left[\sum_{i=1}^{4}\left\{\left(I_{i j}-I_{i k}\right)^{2} / \operatorname{Var}(i)\right\} / 4\right]
$$

where

$I_{i j}$ : Index for cultural dimension $i$ th of the foreign country $j$ th $I_{i k}$ : Index for cultural dimension $i$ th of the foreign country $k$ th $\operatorname{Var}(i)$ : Variance of the index of the dimension $i$ th

\section{3) Moderating Effect Variables}

In addition to the hypotheses about the entry mode choice, we controlled for a number of factors known to impact on mode choice by MNEs. Thus, in testing our model, we wish to include the following control variables at all three levels: country-specific, industry-specific, and firm-specific level.

Country-specific control variables include gross domestic product (GDP) per capita in host country; population of a host country; and annual inflow of FDI as a percentage of GDP.
Data of country-specific variables were generated from United Nation Conference on Trade and Development (UNCTAD)'s Handbook of Statistics and World Investment Report 2007. All data were calculated for the year preceding the year of entry.

Industry-specific control variables include R\&D intensity and advertising intensity. Data were generated from TEJ and calculated for the year prior to the year of entry.

Firm-specific control variables include parent firm size (the number of employees); and previous FDI experience (the number of years that had elapsed since the MNE's first FDI). Data of the firm-specific control variables were also obtained from M.O.P.S and TEJ. All data were calculated for the year preceding the entry year.

\section{RESEARCH RESULTS}

The correlations among the variables were in the predicted directions and consistent with theoretical expectations. These correlations were moderate, with one intercorrelations approaching 0.40 as would be expected. Thus, multicollinearity was not a problem in our research. The means, standard deviations, and intercorrelations for the independent variables are presented in Table 1 . The result of the binary regression analysis is provided in Table 2 .

In Table 2, Model 1 is the baseline model that includes only the intercept and control variables. In Model 2, the coefficient of cultural distance variable is negative and significant at $p<$ 0.001 level, thus supporting Hypothesis 1. Compared to the Model 1, the inclusion of cultural distance variable increased the model's power significantly as indicated by $x^{2}$ increase of 36.523 at statistical level of $p<0.001$.

For the test of Hypothesis 2, the MNE's prior experience in the host country where it has its subsidiaries was entered as shown in the Model 3. As expected, this variable showed a strong positive sign $(p<0.001)$ which means that once the MNE already had previous experience in the host country before the entry, MNE is more likely to choose wholly-owned subsidiary mode over joint-venture modes. Our regression model that has $\mathrm{x}^{2}$ increase of 24.577 from the baseline model was also significant at $p<0.001$. In support of Hypothesis 3, the MNEs' corporate culture diversity was found statistically significant on the selection of wholly-owned subsidiary mode over joint-venture mode as shown in Model 4. As predicted, corporate culture diversity was also found significant at $p<$ 0.001 . This result has provided support to our theoretical development that cultural diversity at corporate level is also a significant determinant in international expansion strategies by MNEs.

\section{CONCLUSION AND DISCUSSION}

\section{Contributions of the Research}

First, our research proposed and tested a model of factors 
Table 1. Descriptive statistics and intercorrelations.

\begin{tabular}{|c|c|c|c|c|c|c|c|c|c|c|c|c|}
\hline Variables & Mean & Std. & 1 & 2 & 3 & 4 & 5 & 6 & 7 & 8 & 9 & 10 \\
\hline 1. Decision (WOSs vs. JVs) & 0.39 & 0.49 & & & & & & & & & & \\
\hline 2. GDP per capita & 2.20 & 1.24 & 1.00 & & & & & & & & & \\
\hline 3. Population of host country & 0.37 & 0.48 & -0.25 & 1.00 & & & & & & & & \\
\hline 4. Annual inflow of FDI & 7.20 & 11.59 & -0.24 & 0.49 & 1.00 & & & & & & & \\
\hline 5. Number of employees & 2.94 & 1.24 & 0.07 & 0.05 & 0.01 & 1.00 & & & & & & \\
\hline 6. Research intensity & 8.51 & 3.76 & -0.05 & 0.01 & -0.01 & 0.09 & 1.00 & & & & & \\
\hline 7. Advertising Intensity & 4.46 & 2.58 & 0.04 & 0.01 & 0.02 & 0.03 & -0.27 & 1.00 & & & & \\
\hline 8. FDI experience (accumulated) & 3.93 & 5.42 & -0.01 & -0.05 & -0.05 & -0.12 & 0.07 & 0.02 & 1.00 & & & \\
\hline 9. Cultural distance & 5.91 & 5.35 & -0.43 & 0.23 & 0.03 & -0.01 & 0.01 & -0.01 & 0.00 & 1.00 & & \\
\hline 10. Prior experience in host country & 0.89 & 0.32 & -0.03 & -0.03 & -0.06 & 0.04 & 0.03 & 0.01 & -0.10 & -0.06 & 1.00 & \\
\hline 11. Corporate culture diversity & 5.53 & 6.37 & -0.09 & 0.00 & 0.07 & -0.27 & -0.01 & -0.04 & -0.49 & 0.07 & 0.08 & 1.00 \\
\hline
\end{tabular}

$N=313 ; * p<0.05$.

Table 2. Results of the logistic regression analysis.

\begin{tabular}{|c|c|c|c|c|c|}
\hline Variables & Model 1 & Model 2 & Model 3 & Model 4 & Model 5 \\
\hline Constant & 1.050 & 2.389 & 1.466 & $2.331 * * *$ & $4.366^{* *}$ \\
\hline GDP per capita & $-.665 * * *$ & -.140 & $-.790 * * *$ & $-.751 * * *$ & $-.412 * *$ \\
\hline Population of host country & .054 & -.107 & -.003 & .011 & $-.224 * *$ \\
\hline Annual inflow of FDI & -.069 & $-.214 * *$ & -.186 & -.018 & $-.294 * *$ \\
\hline Number of employees & $-.076^{* * *}$ & .081 & -.004 & $-.288 * *$ & $-.060 * *$ \\
\hline Research intensity & $.026 * *$ & $.041^{* *}$ & -.034 & .034 & .060 \\
\hline Advertising intensity & .004 & -.001 & -.007 & .003 & -.012 \\
\hline FDI experience (accumulated) & $.045^{* *}$ & .035 & .031 & -.017 & $-.047 * *$ \\
\hline Cultural distance & & $-.949 * * *$ & & & $-.926^{* * *}$ \\
\hline Prior experience in host country & & & $1.398 * * *$ & & $1.511^{* * *}$ \\
\hline Corporate culture diversity & & & & $.097 * * *$ & $.094 * * *$ \\
\hline $\begin{array}{l}-2 \text { Log Likelihood } \\
\end{array}$ & 357.603 & 321.080 & 333.026 & 325.772 & 273.511 \\
\hline $\mathrm{N}$ & 313 & 313 & 313 & 313 & 313 \\
\hline
\end{tabular}

Dependent variable: The likelihood of selection of WOSs over JVs.

$* * * p<0.001 ; * * p<0.01 ; * p<0.10$.

that influence the entry mode choice in international expansion strategy by MNEs. Our model proposed that not only culture distance at national level and prior experience by the MNE in a host country, but also the culture diversity of the MNE itself has a strong effect on the decision making process of entry mode choice.

In addition, the results of the study have confirmed the traditional view that the amount of cultural learning needed in a particular host country is an important determinant of mode choice in FDIs. However, less traditionally, the finding of our research that corporate culture diversity reflects the capacity of an MNE in understanding foreign cultures had a significant increasing effect on the selection of wholly-owned subsidiary mode over joint-venture mode seems to provide an important contribution to this field of research. Most importantly, the novelty of our research is that we have successfully formulated an operationalization of a new construct - the culture diversity at corporate level, a step beyond the national level. The culture diversity reflects the level that an MNE exposes to foreign cultures. Our result contributes to support the importance of the concept of corporate culture diversity. The operationalization of this construct has also been tested and found significant in our empirical test.

Finally yet importantly, even we do not intend to elaborate on the effect of control variables in our research, we do seek to clarify their effect in relation to the mode choice. In harmony with our prediction, the number of years accumulated in FDI by a MNE has a positive and significant effect on the selection of wholly-owned subsidiary mode over the joint-venture mode (significant at $p<0.01$ ). This implies that Taiwanese MNEs in semiconductor industry tend to take full control level of its foreign subsidiaries if a certain number of years have been accumulated since its first foreign investment. However, contradictory to the previous research findings, GDP per capita has a negative and significant effect on the selection of whollyowned subsidiary mode over the joint-venture mode (significant at $p<0.10$ in the full model - Model 5). This finding implies that Taiwanese MNEs in semiconductor industry tend 
to select wholly-owned subsidiary in countries with lower GDP per capita level. This is contradictory to previous research findings that MNEs are more likely to choose jointventure than wholly-owned subsidiary in less developed countries [28]. Other control variables regarding the attractiveness of the host countries - including population of host countries and annual inflow of FDI - are found statistically significant on the decision of selection of wholly-owned subsidiary mode over the joint-venture mode as well. This would imply that Taiwanese MNEs in semiconductor industry prefer to go to primitive market where they can enjoy the larger room of FDIs. For firm specific variable, parent firm size, represented by the number of employees was found significant too. This is contrary to what implied in literature that large firms are more likely to enter foreign markets through a mode of full control level than are small firms [8].

In addition to the national cultural difference as determinant of entry mode that has dominated in the literature, our research makes a significant contribution to practitioners. Specifically, it gives top management new insight for examining their organizations when making the entry decision to a nearby culture for instance. It also provides valuable directions in which managers could analyze competitors' entry mode choices by studying organizations' intrinsic values such as corporate culture diversity.

\section{Limitation and Future Research Direction}

While this research is innovative and significantly contributive to organizational theory, it is not without limitations. First, our sample was restricted to publicly owned firms. Differences can be found between publicly and privately owned firms. Public ownership can facilitate stockholder diversification, increase liquidity, and raise funds more easily. However, Taiwan Financial and Supervisory Commission (FSC) and pubic investors impose stricter constraints on the operations of publicly owned firms. Second, we examine the MNEs' entry mode choice preferability and test the operationalization of a new construct of culture diversity at corporate level by drawing from a sample of Taiwanese population in semiconductor industry. Future research could test on other organizational population of MNEs or a mix to examine whether the findings and the operationalization of the construct tested in our research could be generalized beyond the Taiwanese context and across industries.

\section{REFERENCES}

1. Barkema, H. G., Bell, J. H., and Pennings, J. M., "Foreign entry, cultural barriers, and learning," Strategic Management Journal, Vol. 17, pp. 151166 (1996).

2. Barkema, H. G. and Drogendijk, R., "Internationalising in small, incremental or larger steps?” Journal of International Business Studies, Vol. 38, No. 7, pp. 1132-1148 (2007).

3. Brouthers, K. D., "Institutional, cultural and transaction cost influences on entry mode choice and performance," Journal of International Business Studies, Vol. 33, No. 2, pp. 203-221 (2002).

4. Brouthers, K. D. and Brouthers, L. E., "Why service and manufacturing entry mode choices differ: the influence of transaction cost factors, risk and trust," Journal of Management Studies, Vol. 40, No. 5, pp. 1179-1204 (2003).

5. Brouthers, K. D. and Hennart, J. F., "Boundaries of the firm: insights from international entry mode research," Journal of Management, Vol. 33, No. 3, pp. 395-425 (2007).

6. Canabal, A. and White III, G. O., "Entry mode research: Past and future," International Business Review, Vol. 17, pp. 267-284 (2008).

7. Caves, R. E., Multinational Enterprise and Economic Analysis, Cambridge University Press, Cambridge (1982).

8. Caves, R. E. and Mehra, S., "Entry of foreign multinationals into U.S. manufacturing industries," In: Porter, M. (Ed.), Competition in Global Industries, Harvard Business School, Boston (1986).

9. Chang, S. J. and Rosenzweig, P. M., "The choice of entry mode in sequential foreign direct investment," Strategic Management Journal, Vol. 22, pp. 747-776 (2001).

10. Cohen, W. M. and Levinthal, D. A., "Absorptive capacity: New perspective on learning and innovation," Administrative Science Quarterly, Vol. 35, pp. 128-152 (1990).

11. Colonques, R. M., Orts, V., and Monerris, J. J. S., "Entry in foreign markets under asymmetric information and demand uncertainty," Southern Economic Journal, Vol. 74, No. 4, pp. 1105-1122 (2008).

12. Criscuolo, P. and Narula, R., "A novel approach to national technological accumulation and absorptive capacity: aggregating Cohen and Levinthal," European Journal of Development Research, Vol. 20, No. 1, pp. 56-73 (2008).

13. Darroch, J., "Knowledge management, innovation and firm performance," Journal of Knowledge Management, Vol. 9, No. 3, pp. 101-115 (2005).

14. Davidson, W. H., Global Strategic Management, John Wiley and Sons, New York (1982).

15. Gatignon, H. and Anderson, E., "The multinational enterprise's degree of control over foreign subsidiaries: An empirical test of a transaction cost explanation," Journal of Law, Economics, and Organization, Vol. 4, pp. 305-336 (1988).

16. Hennart, J. F. and Park, Y. R., "Greenfield versus acquisition: The strategy of Japanese investors in the United States," Management Science, Vol. 39, pp. 1054-1070 (1993).

17. Hofstede, G., Culture's Consequences: International Differences In Workrelated Values, Sage Publications, Beverly Hills (1980)

18. Hofstede, G. and Hofstede, G. J., Cultures and Organizations: Software of The Mind, McGraw-Hill, New York (2005).

19. Johanson, J. and Vahlne, J. E., "The internationalization process of the firm: A model of knowledge development and increasing foreign market commitments," Journal of International Business Studies, Vol. 8, pp. 23-32 (1977).

20. Kogut, B. and Singh, H., "The effect of national culture on the choice of entry mode," Journal of International Business Studies, Vol. 19, No. 3, pp. 411-432 (1988).

21. Lu, J. W., "Intra- and inter-organizational imitative behavior: Institutional influences on Japanese firms' entry mode choice," Journal of International Business Studies, Vol. 55, No. 1, pp. 19-37 (2002).

22. Lu, L. T., "The relationship between cultural distance and performance in international joint ventures: a critique and ideas for further research," International Journal of Management, Part 1, Vol. 23, No. 3, pp. 436-445 (2006).

23. Luo, Y., "Capability exploitation and building in a foreign market: Implications for multinational enterprises," Organization Science, Vol. 13, No. 1, pp. 48-63 (2002).

24. Makino, S. and Neupert, K. E., "National culture, transaction costs, and the choice between joint venture and wholly owned subsidiary," Journal of International Business Studies, Vol. 31, No. 4, pp. 705-713 (2000).

25. Mani, S., Antia, K. D., and Rindfleisch, A., "Entry mode and equity level: A multilevel examination of foreign direct investment ownership structure," Strategic Management Journal, Vol. 28, No. 8, pp. 857-866 (2007).

26. Perkins-Rodriguez, S., "Institutional environment relatedness and foreign 
investment failure in the Brazilian telecommunication industry," Academy of Management Proceedings, Honolulu, pp. t1-t6 (2005).

27. Root, F. J., Entry Strategies for International Markets, Jossey-Bass, CA 94104 (1998).

28. Shan, W., "Environmental risks and joint venture sharing arrangements," Journal of International Business Studies, Vol. 22, pp. 555-578 (1991).

29. Shapiro, D., Yao, T., and Xuejing, C., "Mode of entry and the regional distribution of foreign direct investment in China," Journal of Chinese Economic \& Business Studies, Vol. 5, No. 3, pp. 261-277 (2007).

30. Tihanyi, L., Griffith, D. A., and Russell, C. J., "The effect of cultural distance on entry mode choice, international diversification, and MNE performance: A meta-analysis," Journal of International Business Studies, Vol. 36, No. 3, pp. 270-283 (2005). 